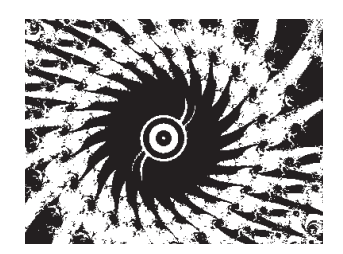

doi:10.5559/di.21.1.10

\title{
PARANORMAL BELIEFS AND PERSONALITY TRAITS IN CROATIA
}

Igor MIKLOUŠıĆ, Boris MLAČIĆ, Goran MILAS

Institute of Social Sciences Ivo Pilar, Zagreb

UDK: 159.923.2(497.5):133

Izvorni znanstveni rad

Primljeno: 27. 9. 2010.

The goal of this study was to assess the relationship between the Five Factor Model of personality and the belief in the paranormal. Participants $(\mathrm{N}=307)$ were students from the University of Zagreb, Croatia. The measures used were the IPIP version of the Five Factor Model questionnaire (Goldberg et al., 2006) along with the Revised Paranormal Belief Scale (Tobacyk, 1988). The factor analysis of the latter yielded three previously unreported paranormal belief dimensions named: General paranormal belief, Traditional religious belief and Rituals and practices. The most significant personality correlations with all three factors were found for Openness, Conscientiousness and Neuroticism, respectively. Results to an extent confirmed previous findings, suggesting that open individuals accept more General paranormal beliefs, while rejecting Traditional religious belief. Conscientiousness displayed an opposite trend being positively related to Traditional religious beliefs and negatively to General paranormal beliefs. Finally, Neuroticism was related to Rituals and practices, i.e. superstitions, divinations and occult control of life outcomes. The relations are however modest ranging from 0.11 to 0.25 . Both the novel paranormal belief structure and its significance to personality are discussed within an evolutionary perspective, with guidelines for further research highlighted in the end.

Keywords: paranormal beliefs, personality traits, Tobacyk, Five Factor Model, evolution

$\square$ Igor Mikloušić, Institute of Social Sciences Ivo Pilar, Marulićev trg 19/1, P. O. Box 277, 10000 Zagreb, Croatia.

E-mail: Igor.Miklousic@pilar.hr 


\section{INTRODUCTION}

From ghosts to haunted houses and lucky rabbit paws, paranormal beliefs are fascinating phenomena. Gallup polls show that about three in four Americans profess at least one paranormal belief (Moore, 2005) with possession by the devil (41\%), extra sensory perception (41\%) and haunting (37\%) being currently most popular. In Croatia, although more moderate, the results differ only slightly, with one out of four people believing in the possession by the devil, lucky charms and ghosts (Marinović-Jerolimov, 2005). However, despite a rather large body of research dealing with these phenomena (for overview see Irwin, 1993, 2009), the contribution of personality to formation and persistence of paranormal beliefs has not been adequately explored. Studies on this subject have been hindered by conceptual and methodological issues, making the available findings for the most part uninterpretable and inconclusive. The aim of our study was therefore to explore the dimensionality of paranormal beliefs in a Croatian student sample and examine the relations between paranormal beliefs and personality dimensions using two of the most widely used and validated measures from both fields.

\section{Paranormal beliefs; Defining and measuring an elusive concept}

Psychological research into the paranormal is as old as psychology itself, with William James, known as the father of North American psychology, being a prominent researcher into the supernatural (Coon, 1992). Regardless of its historic roots however, the progress of paranormal belief research has been slow, hindered mostly by the lack of consensus on the object of the study. What started as an exploration of superstitions (Irwin, 2009), soon grew to include various other constructs, but without any agreement over exactly what should be considered paranormal belief. The latest definition suggested they pertain to phenomena not empirically attested to the satisfaction of the scientific establishment, with the addition of arising in a broader community as a non-scientific commonsense endeavor to account for anomalous experiences (Irwin, 2009). Nevertheless, a consensus is far from being reached, making it a source of significant confusion between the researchers, and causing the construct of paranormal beliefs to be considered a methodological nightmare. A plethora of available questionnaires (e.g. Gallagher et al., 1994; Thalbourne \& Delin, 1993; Tobacyk, 1988) also differ significantly in their views on dimensionality and the scope of paranormal beliefs. This in turn makes comparison of the findings from studies using different measures extremely questionable. Fortunately, a somewhat informal agreement has been achieved with the (Revised) 
DRUŠ. ISTRAŽ. ZAGREB GOD. 21 (2012),

BR. 1 (115)

STR. 181-201

MIKLOUŠIĆ, I., MLAČIĆ, B., MILAS, G.:

PARANORMAL BELIEFS.
Paranormal Belief Scale (RPBS) conceived by Tobacyk and Milford (1983; Tobacyk, 1988) and used in most of the studies on paranormal belief since the mid eighties (Irwin, 1993, 2009; Lawrence, 1995a). Out of a variety of items included, the authors (Tobacyk \& Milford, 1983) extracted seven broad factors they considered to represent seven distinct dimensions of paranormal belief. The factors were named; Traditional religious beliefs, Psi, Witchcraft, Superstition, Spiritualism, Extraordinary life forms and Precognition. Although still accepted by some researchers, the seven dimensions were later thoroughly criticized for being logically and empirically unfounded (Lawrence, 1995a; 1995b). However, the liberal criteria of inclusion allowed for the scale to be considered a reliable taxonomy of paranormal beliefs, enabling various other researchers to explore the structure of the RPBS in search of broader and theoretically more valid dimensions. The suggestions varied from five (Lawrence \& De Cicco, 1997; Lawrence et al., 1997), four (Hartman, 1999) and two (Lange et al., 2000), to even one latent factor (Thalbourne et al., 1995). Unfortunately, all of these proposed structures have been poorly empirically tested, and for the most part without any theoretical explanation. This made the dimensionality of paranormal beliefs still an open issue. Especially since there have been indications that the structure of paranormal beliefs, assessed with RPBS, is culturally dependent (Díaz-Vilela \& Álvarez-González, 2004; Tobacyk \& Thomas, 1997).

\section{Origins of paranormal beliefs and the role of personality}

Besides the dimensionality, another significant issue in understanding paranormal beliefs are the highly inconsistent results regarding the relationship with various personality characteristics. Five major factors of personality (Costa \& McCrae, 1992) are amongst the most neglected domains in that aspect. Much of the early research with personality correlations of paranormal belief focused on smaller scope constructs such as locus of control (Tobacyk \& Milford, 1983), and sensation seeking (Tobacyk \& Milford, 1983) dogmatism (Alcock \& Otis, 1980; Thalbourne et al., 1995), narcissism (Tobacyk \& Mitchell, 1987) and even psychopathological indices like schizotipy (Goulding, 2005; Tobacyk and Wilkinson, 1990), manic-depression (Thalbourne \& French, 1995) and schizophrenia (Thalbourne, 1994). However, with regard to the now widely accepted and almost paradigmatic, Five Factor Model of personality (Costa \& McCrae, 1992), there hasn't been much research that we could relate to or draw instances from. Even studies dealing with somewhat comparable dimensions of personality (e.g. Eysenck's 
DRUŠ. ISTRAŽ. ZAGREB GOD. 21 (2012),

BR. 1 (115),

STR. 181-201

MIKLOUŠIĆ, I., MLAČIĆ, B., MILAS, G.:

PARANORMAL BELIEFS... always highly inconsistent. For example, even though there has been some evidence on paranormal believers being more extraverted (Thalbourne \& Haraldsson, 1980), all subsequent research using different measures of paranormal beliefs and personality found no such relation (e.g. Rattet \& Bursik, 2001; Thalbourne et al., 1995). On the other hand, the dimension that has found the most support in being related to paranormal beliefs is Neuroticism. Windholz and Diamant (1974) were the first to characterize believers in paranormal as impulsive, reflective, neurotic and even schizoid, as opposed to controlled, practical, and well-adjusted non-believers. That finding was later replicated using various measures of both Neuroticism and paranormal belief (e.g. Gallagher et al., 1994; Thalbourne et al., 1995). In more recent studies, Neuroticism was found to be the best predictor of paranormal beliefs within Eysenck's three factor model (Williams et al., 2007), a significant predictor of both positive and negative superstitions (Wiseman \& Watt, 2004), astrology (Fichten \& Sunerton, 1983), and a useful predictor of magical-religious beliefs in a large Finnish sample $(\mathrm{N}=3261)$ (Lindeman \& Aarnio, 2006). Despite the majority of confirming studies, some nevertheless found no relationship between Neuroticism and paranormal beliefs (e.g. MacDonald, 2000; Tobacyk, 1982). It is also worth noting that Neuroticism is one of the dimensions of the Five Factor model most consistently related to religiosity (Saroglou, 2002; Saroglou \& Jaspard, 2000). Despite the statistically significant relation however, the direction has been both positive and negative, making it difficult to interpret. Studies exploring Conscientiousness and Agreeableness as correlates of paranormal belief have been somewhat more consistent, albeit very scarce. Surprisingly, although those two dimensions play a major role in explaining the relationship between religiousness and personality (see Saroglou, 2002), and efficiently differentiate traditional religious beliefs from more spiritual approaches to religion (Saucier, 2000; Saucier \& Skrzypiska, 2006), their relation to other paranormal beliefs has not been well documented. In those rare studies only Conscientiousness was shown to have a negative relation to paranormal belief (i.e. Egan et al., 1999). Finally, Openness to experience, characterized by receptiveness to new ideas, approaches, and experiences (McCrae \& Costa, 1997), was also fairly consistently shown to correlate with general paranormal belief (Egan et al., 1999; MacDonald, 2000; Smith et al., 2009). However, as with all other dimensions, the diverse measures of both personality and paranormal beliefs used, along with a small number of studies conducted, make it impossible to conclusively determine the relevance of this personality dimension in explaining and predicting paranormal beliefs. 
DRUŠ. ISTRAŽ. ZAGREB GOD. 21 (2012),

BR. 1 (115),

STR. 181-201

MIKLOUŠIĆ, I., MLAČIĆ, B., MILAS, G.:

PARANORMAL BELIEFS.
Due to the above stated issues, the two problems addressed in our study were; the structure of the RPBS; and the relation between paranormal belief and personality. The first problem is an important one, since there is still little agreement between the researchers on the number of dimensions defining paranormal beliefs. Overestimating as well as underestimating the number of distinct constructs within the RPBS could pose a threat in an attempt to find real relationships with personality dimensions and explain them in a theoretically sound way. With regard to the second problem, we can put forth several hypotheses. Firstly, due to the lack of significant findings in recent studies, conducted with somewhat comparable measures (e.g. Williams et al., 2007), we do not expect to find a significant relationship between paranormal beliefs and extraversion. Furthermore, as Agreeableness and Conscientiousness dimensions have seldom been studied outside of traditional religious beliefs, our inferences can be made mostly on the basis of prior religiosity research. In that regard, we could expect Conscientiousness to be positively correlated to traditional religious beliefs (Saroglou, 2002). This is presumed due to conscientious people being characterized by impulse control, need for orderliness, and low flexibility (Costa \& McCrae, 1992). Also, since all other paranormal beliefs are usually labeled as unconventional or even bizarre, it is sound to presume that negative correlation would be found between those scales and Conscientiousness (Egan et al., 1999). Regarding Agreeableness, which emphasizes both compliance and prosocial tendencies, we could presume that if adherence to traditional authority-based religion were strongly normative in a culture, endorsement of attitudes representing doctrines of this religion should become highly desirable for individuals and thus more related to this dimension (Saucier \& Skrzypiska, 2006). Since the population of Croatia is predominantly Catholic, the measurement of tradition-oriented religiousness should become strongly affected by desirability responding, and thus related to an extent to Agreeableness. Furthermore, the prosocial tendencies displayed by the Agreeableness dimension, should manifest themselves through a benevolent worldview promoted by various spiritual claims. These presumptions are supported by the prior positive relationship with both traditional and spiritual dimensions of religiosity (Saroglou, 2002; Saucier, 2000; Saucier \& Skrzypiska, 2006), and could imply a positive relation of Agreeableness with Traditional religious belief and Spiritualism subscales of RPBS. Since it has been implied how a need for security could be the underlying cause of more neurotic people adopting paranormal beliefs (Thalbourne et al., 1995), we also expect to find a significant corre- 
DRUŠ. ISTRAŽ. ZAGREB

BR. 1 (115),

STR. 181-201

MIKLOUŠIĆ, I., MLAČIĆ, B., MILAS, G.:

PARANORMAL BELIEFS... GOD. 21 (2012),

lation between Neuroticism and paranormal beliefs. More specifically, Neuroticism is presumed to be most strongly correlated with Superstition, Traditional religious beliefs and possibly Precognition, as those subscales imply a certain determination, predictability and a sense of control. However, Neuroticism has also been negatively related to Religious fundamentalism and Orthodoxy (Saroglou, 2002), making it difficult to formulate adequate predictions on the direction of this relationship. Finally, a more precise hypothesis can be made in regard to the Openness dimension. This dimension has been the most important predictor of religiosity (Saucier \& Skrzypińska, 2006), and paranormal beliefs (Egan et al., 1999; MacDonald, 2000; Smith et al., 2009) within the Five Factor Model. Presumably, receptiveness to new ideas, approaches, and experiences as captured by the Openness factor (McCrae \& Costa, 1997), leads away from traditionally rigid religious beliefs and toward more stimulating beliefs and worldviews. We therefore expect Openness to be negatively related to Traditional paranormal belief while positively related to all concepts regarding Psi, Spirituality, Precognition, and Extraordinary life forms.

\section{METHOD}

\section{Participants}

The participants were 307 undergraduate students from the University of Zagreb, of whom $88.3 \%$ were women. The average age of participants was 21.9 years $(\mathrm{SD}=2.5$, range $19-45)$. All participants were students of social and humanistic disciplines, most of them studying psychology $(\mathrm{N}=217)$ and educational-rehabilitation sciences $(\mathrm{N}=59)$. The majority $(78.4 \%)$ reported being Christian, with $16.1 \%$ being atheist or agnostic, and the rest reported some other religious affiliation. The study was conducted in classroom settings. Subjects were approached at the beginning of the class and asked to participate in the study. Participation was voluntary, and the subjects willing to participate were given enough time to fill out included measures. Although fairly common and comparable to most of the studies on this subject, we must note that this was a convenience sample which could have an effect on the results.

\section{Measures}

Paranormal beliefs were measured using the Revised Paranormal Belief Scale (RPBS) by Tobacyk (1988). The 26-item scale provides a result on seven dimensions of paranormal beliefs: Traditional religious belief (e.g. There is a devil), Psi (e.g. A person's thoughts can influence the movement of a physical object), Witchcraft (e.g. Witches do exist), Superstition (e.g. Black cats can 
DRUŠ. ISTRAŽ. ZAGREB GOD. 21 (2012),

BR. 1 (115),

STR. 181-201

MIKLOUŠIĆ, I., MLAČIĆ, B., MILAS, G.:

PARANORMAL BELIEFS. bring bad luck), Spiritualism (e.g. Your mind and soul can leave your body and travel), Extraordinary life forms (e.g. The Loch Ness monster of Scotland exists) and Precognition (e.g. Astrology is the way to accurately predict the future). The responses are scored on a seven-point Likert scale. Higher rating indicates stronger endorsement on all but one item from the Psi subscale (23. Mind reading is not possible) which in turn needs to be negatively scored (Tobacyk \& Milford, 1983). The sum of all items is indicative of a general tendency to adopt paranormal belief, while subscales can be used to measure specific dimensions of paranormal belief (Tobacyk, 1988). Since this was the first use of this scale in Croatia, in order to assure the adequacy of translation, a standard translation/back-translation procedure was conducted by the authors. During this procedure none of the items were perceived as culturally unrecognizable and unfamiliar, therefore no items were replaced. The only slight reformulation was in renaming the "Abominable snowman of Tibet" to "Yeti", since the former has no direct translation in Croatian.

Personality factors were assessed by a 50-item International Personality Item Pool (IPIP, Goldberg et al., 2006; http://ipip. ori.org/) aimed to measure Costa and McCrae's (1992) Five Factor Model. This measure consists of 50 short statements in which every dimension: Neuroticism, Extraversion, Agreeableness, Conscientiousness and Openness, are represented by 10 items. We decided to use the Five Factor oriented IPIP measure, in order to include the Openness dimension, which in the Big Five structure is replaced by Intellect. Although there is a significant overlap between the two dimensions (Saucier, 1992), we chose the former due to the number of existing studies regarding its relationship to the paranormal beliefs. The IPIP measure was validated on a Croatian sample by Mlačić and Goldberg (2007), while Gračanin, Kardum and Krapić (2004) adapted the Openness scale. Both adaptations replicated previous findings on the dimensionality of the measures, and showed high reliabilities of all the subscales on the Croatian sample.

\section{RESULTS}

\section{Factor structure of the RPBS (Tobacyk, 1988)}

We focused on the exploration of the original Tobacyk's seven factor structure using the principal axis factor analysis with oblique rotation. In the original study by Tobacyk and Milford (1983), the authors used varimax rotation in their analysis. However, due to subsequent criticism showing high scale intercorrelations, along with lack of theoretical explanation which would support the orthogonality (Lange et al., 2000; Lawrence et al., 
DRUŠ. ISTRAŽ. ZAGREB GOD. 21 (2012),

BR. 1 (115),

STR. 181-201

MIKLOUŠIĆ, I., MLAČIĆ, B., MILAS, G.:

PARANORMAL BELIEFS...

$\rightleftharpoons$ FIGURE

Plot of the eigenvalues on the whole sample using Principal Axis Factoring
1 Due to space limitations, the seven-factor structure of paranormal beliefs was omitted from the text. Interested researchers can obtain detailed results on the psychometric properties of the RPBS from the first author upon request.
1997; Lawrence \& De Cicco, 1997), a consensus on scales not being orthogonal has been reached (Lawrence et al., 1997; Tobacyk \& Thomas, 1997).

As hypothesized, our analysis yielded an interpretable seven factor oblique structure accounting for $69.7 \%$ of the variance, which is in accordance with previous assertions (Tobacyk \& Milford, 1983). ${ }^{1}$ Furthermore, most of the items loaded on their intended factors with the exception of items that have been problematic in the past studies. More specifically, item 23 from the Psi subscale, being the only item in negative form, which was not correlated with the rest of the scale in a Spanish sample (Díaz-Vilela \& Álvarez-González, 2004); items 26 and 21 are both part of the Precognition subscale extensively criticized by Lawrence (1995a) for being composed of two different factors (Tobacyk et al., 1989) mainly precognitive systems (i.e. astrology) and gifted persons (i.e. clairvoyants); and item 20 (There is life on other planets) from the Extraordinary life forms subscale that was argued not to represent paranormal belief but a scientific probability (Lawrence, 1995a). However, the seven factor structure did not prove to be the most suitable factor solution for our data due to both the Scree test (Cattell, 1966) and Horn's (1965) Parallel analysis criteria. We noted a clear discontinuity in the sizes of the eigenvalues between the third and the fourth factor (Figure 1), indicating that the three factor structure should be extracted. This was also confirmed by subsequent parallel analysis that showed all eigenvalues after the third could have been produced by chance. We therefore proceeded with the extraction of the three factors using the principal axis factor analysis with oblique rotation.

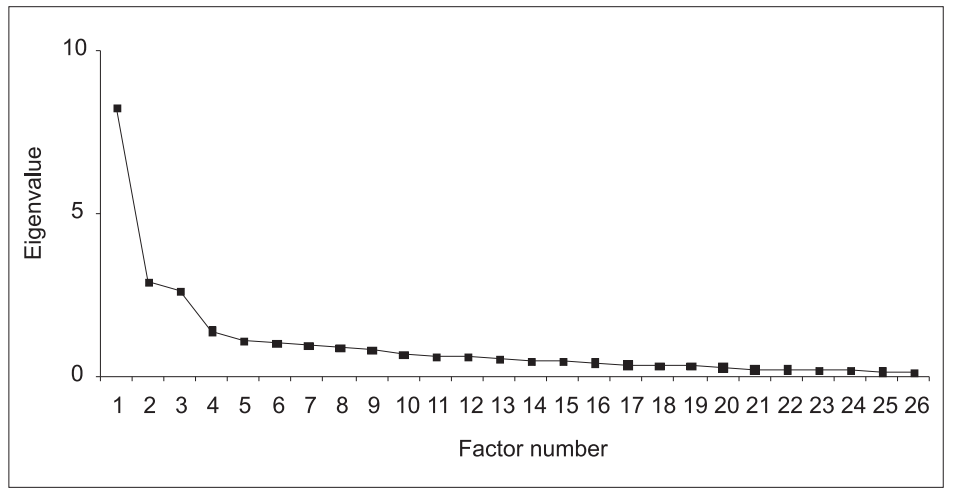

This factor analysis (Table 1) yielded an interpretable three factor structure explaining $52.47 \%$ of the total variance. Upon examination of the item structure, the three factors were named General paranormal belief (GPB), Traditional religious belief (TRB), and Rituals and practices (RAP). 


\begin{tabular}{|c|c|c|c|c|}
\hline & Items & $\begin{array}{r}\text { General } \\
\text { paranormal } \\
\text { belief }\end{array}$ & $\begin{array}{r}\text { Traditional } \\
\text { religious } \\
\text { belief }\end{array}$ & $\begin{array}{r}\text { Rituals } \\
\text { and } \\
\text { practices }\end{array}$ \\
\hline 16. & $\begin{array}{l}\text { A person's thoughts can influence the } \\
\text { movement of a physical object. }\end{array}$ & 0.9 & & \\
\hline 9. & Psychokinesis, the movement of objects through & & & \\
\hline & psychic powers, does exist. & 0.88 & & \\
\hline 2. & $\begin{array}{l}\text { Some individuals are able to levitate (lift) objects } \\
\text { through mental forces. }\end{array}$ & & & \\
\hline 5. & $\begin{array}{l}\text { Your mind or soul can leave your body and travel } \\
\text { (astral projection). }\end{array}$ & 0.79 & & \\
\hline 12. & $\begin{array}{l}\text { During altered states, such as sleep or trances, } \\
\text { the spirit can leave the body. }\end{array}$ & 0.67 & & \\
\hline 26. & $\begin{array}{l}\text { Some people have an unexplained ability } \\
\text { to predict the future. }\end{array}$ & 0.61 & & \\
\hline 21. & Some psychics can accurately predict the future. & 0.58 & & 0.35 \\
\hline 25. & It is possible to communicate with the dead. & 0.58 & & \\
\hline 3. & Black magic really exists. & 0.53 & 0.32 & \\
\hline 19. & Reincarnation does occur. & 0.51 & & \\
\hline 17. & Through the use of formulas and incantations, & & & \\
\hline & it is possible to cast spells on persons. & 0.46 & & \\
\hline 20. & There is life on other planets. & 0.34 & & \\
\hline 6. & The abominable snowman of Tibet exists. & 0.32 & & \\
\hline 23. & Mind reading is not possible. & 0.31 & & \\
\hline 22. & There is a heaven and a hell. & & 0.88 & \\
\hline 8. & There is a devil. & & 0.81 & \\
\hline 15. & I believe in God. & & 0.69 & \\
\hline & The soul continues to exist though the body may die. & & 0.65 & \\
\hline 11. & If you break a mirror, you will have bad luck. & & & 0.68 \\
\hline 18. & The number "13" is unlucky. & & & 0.67 \\
\hline 4. & Black cats can bring bad luck. & & & 0.56 \\
\hline 14. & The horoscope accurately tells a person's future. & & & 0.55 \\
\hline 24. & There are actual cases of witchcraft. & & & 0.53 \\
\hline 10. & Witches do exist. & & & 0.52 \\
\hline 13. & The Loch Ness monster of Scotland exists. & & & 0.48 \\
\hline 7. & Astrology is a way to accurately predict the future. & & & 0.47 \\
\hline
\end{tabular}

For clarity, only loadings $\geq 0.30$ are indicated in the table

(1) TABLE 1 Three Factor Oblique-Rotated Loadings of the Revised Paranormal Belief Scale (Tobacyk, 1988)
In this solution, the first factor consists mostly of items from Psi and Spiritualism subscales, with Precognition, Witchcraft and Extraordinary life forms items partially included. The second factor contains only the items from Tobacyk's (1988) Traditional religious beliefs scale, whilst the third factor contains items from Superstition subscale and the rest of the items from the Precognition, Witchcraft and Extraordinary life forms subscales. The first and the third factor were most strongly correlated $(0.42, \mathrm{p}<0.001)$. The correlation between the first and the second factor were smaller but still significant $(0.16$, $p<0.001)$, whilst the second and the third factor are not sig- 
DRUŠ. ISTRAŽ. ZAGREB GOD. 21 (2012),

BR. 1 (115),

STR. 181-201

MIKLOUŠIĆ, I., MLAČIĆ, B., MILAS, G.:

PARANORMAL BELIEFS. nificantly correlated $(0.10, \mathrm{p}>0.05)$. The internal consistency reliability estimates (Cronbach alpha) of the three extracted scales ranged from 0.90 for General paranormal belief to 0.84 for Traditional religious belief and 0.80 for Rituals and practices. The reliabilities of seven RPBS subscales calculated according to Tobacyk (1988) were also within acceptable levels, being the highest for Traditional religious beliefs (0.84) and Psi (0.81) while Extraordinary life forms showed rather low reliability (0.53). The Five Factor structure was replicated similarly to previous studies (Mlačić \& Goldberg, 2007) with the five factors explaining $47.46 \%$ of variance. The reliabilities for each of the Five Factor domains were high, ranging from 0.90 for Conscientiousness to 0.72 for Openness and are comparable to those reported by Mlačić and Goldberg (2007).

\section{Correlations of the two RPBS (Tobacyk, 1988) factor solutions and the Five Factor Personality dimensions}

The correlations of personality factors and the scales derived from the seven factor solution (Table 2) show a significant, albeit weak, relationship. As presumed, Conscientiousness, Neuroticism and Openness show highest correlations with paranormal beliefs. More specifically, Conscientiousness confirmed the predictions of being related positively to Traditional religiosity (0.19), and negatively to Psi belief (-0.13). Neuroticism was shown to be positively correlated to Superstition (0.19), Extraordinary life forms (0.16) and Precognition (0.14). Finally, the correlations between personality and paranormal beliefs were the highest for the Openness factor. Its negative relationship with Traditional religious beliefs $(-0.25)$, and posi-

(1) TABLE 2

Correlations between the Five Factor Model and the RPBS seven factor solution tive with belief in Psi (0.16) and Spiritualism (0.25) replicated, to an extent, the findings by Smith et al. (2009). Agreeableness has shown meaningful correlation only with Traditional religious beliefs $(0.15)$.

\begin{tabular}{lllllllc}
\hline & \multicolumn{4}{c}{} & \multicolumn{4}{c}{ RPBS - Seven scales } \\
\cline { 2 - 8 } Personality factors & T REL & PSI & WITC & SUPER & SPIR & ELF & PREC \\
\hline Extraversion & 0.05 & -0.11 & -0.07 & 0.01 & -0.10 & -0.02 & -0.00 \\
Conscientiousness & $0.19^{* *}$ & $-0.13^{*}$ & -0.07 & 0.04 & -0.11 & -0.06 & -0.01 \\
Agreeableness & $0.15^{*}$ & -0.02 & -0.04 & -0.08 & -0.02 & -0.11 & -0.06 \\
Neuroticism & 0.00 & -0.04 & 0.08 & $0.19^{* *}$ & 0.08 & $0.16^{* *}$ & $0.14^{*}$ \\
Openness & $-0.26^{* *}$ & $0.16^{* *}$ & 0.00 & -0.02 & $0.25^{* *}$ & 0.09 & -0.02 \\
\hline
\end{tabular}

Note. ${ }^{*} \mathrm{p} \leq 0.05 ;{ }^{* *} \mathrm{p} \leq 0.001$ (shown in italics); for RPBS: T REL $=$ Traditional religious belief, PSI $=$ Psi, WITC $=$ Witchcraft, $\mathrm{SUPER}=$ Superstition, $\mathrm{SPIR}=$ Spiritualism; ELF $=$ Extraordinary life forms, PREC $=$ Precognition 
DRUŠ. ISTRAŽ. ZAGREB GOD. 21 (2012),

BR. 1 (115)

STR. 181-201

MIKLOUŠIĆ, I., MLAČIĆ, B., MILAS, G.:

PARANORMAL BELIEFS.

(1) TABLE 3

Correlations between the Five Factor Model and the RPBS three factor solution the dynamic becomes more evident and easily interpretable. Neuroticism was significantly related to Rituals and practices (RAP) factor (0.23) since that factor subdued all its significant correlates from the seven factor structure. Conscientiousness retained its negative relationship to Psi through the General paranormal belief (GPB) factor $(-0.13)$, while the positive relationship with Traditional religious belief (TRB) remained nearly the same (0.17), as the new factor consisted of all the items from Tobacyk's (1988) Traditional religious beliefs subscale. Agreeableness and Openness preserved their relationship to TRB as well, being 0.13 and -0.25 respectively. Openness was also positively related to the GPB (0.19), presumably since GPB includes items from both Spirituality and Psi domains. Finally, a significant correlation between Extraversion and GPB emerged in this structure.

\begin{tabular}{lccc}
\hline & & \multicolumn{2}{c}{ RPBS - Three factor solution } \\
\cline { 2 - 4 } Personality factors & GEN PARA & TRAD REL & RIT PRACT \\
\hline Extraversion & $-0.11^{*}$ & 0.04 & 0.00 \\
Conscientiousness & $-0.13^{*}$ & $0.17^{* *}$ & -0.01 \\
Agreeableness & -0.04 & $0.13^{*}$ & -0.11 \\
Neuroticism & 0.03 & 0.01 & $0.23^{* *}$ \\
Openness & $0.19^{* *}$ & $-0.25^{* *}$ & 0.02 \\
\hline
\end{tabular}

Note. ${ }^{*} \mathrm{p} \leq 0.05 ;{ }^{* *} \mathrm{p} \leq 0.001$ (shown in italics); for RPBS: GEN PARA = General paranormal belief; TRAD REL $=$ Traditional religious belief; RIT PRACT $=$ Rituals and practices

\section{DISCUSSION}

In this paper we set out to explore the dimensionality of paranormal beliefs in a Croatian student sample and examine the relations between paranormal beliefs and personality using two of the most widely used and validated measures from both domains. Most of our initial hypotheses regarding relation between personality and paranormal beliefs were proven true, with some of the previously non established relations opening room for novel approaches to the subject. As in most of the previous empirical research on the dimensionality of the RPBS, we were able to replicate the seven factor structure suggested by the authors (Tobacyk \& Milford, 1983). The problematic items mostly related to the previously criticized Precognition scale (Lawrence, 1995a) and other items that could be easily misinterpreted as non-paranormal statements (e.g. There is life on other planets). However, another, more parsimonious structure of paranormal belief was shown to exist. This finding is in accord with a large number of studies that either presumed a lesser number of factors on the basis of the logical analysis (Lawrence, 1995a; 1995b), or empirical studies 
DRUŠ. ISTRAŽ. ZAGREB GOD. 21 (2012), BR. 1 (115),

STR. 181-201

MIKLOUŠIĆ, I., MLAČIĆ, B., MILAS, G.:

PARANORMAL BELIEFS.. suggesting that a lesser number of factors could provide a better fit of the data (e.g. Hartman, 1999). After analyzing the data, both the Scree test (Cattell, 1966) and parallel analysis (Horn, 1965) suggested the data supported three factors. Upon extracting those factors, we found the items distributed meaningfully and most significantly on the three factors, with no items being left out or having dual projections. This finding was in accord with the proposition by the authors (Tobacyk \& Thomas, 1997) that the seven RPBS dimensions do not necessarily represent the "correct" structure of paranormal beliefs, but rather a construction dependent on a socio-cultural context and the level of analysis selected by the investigator. Each of the seven RPBS dimensions can therefore be represented by higher-order dimensions that might prove to be more meaningful and useful in construction of an integrative model of the explored domain (Tobacyk, 1995). Tobacyk \& Thomas (1997) also state that together with statistical indicators, the new paranormal belief dimensions should also have a heuristic value and be able to explain important psychologi$\mathrm{cal}$ and behavioral processes of the person in order for a dimensionality to be considered relevant. We will therefore address these issues through the findings of this study. In regard to the seven factor structure (Table 2), significant correlations were found between all the personality dimensions we presumed to be related to paranormal beliefs. More specifically, Neuroticism, Conscientiousness and Openness confirmed the hypothesis regarding their relation to Superstition, Traditional religious beliefs, and Psi, respectively. Some results however were not predicted, as for instance the positive relation between Neuroticism and Extraordinary life forms, or the lack of negative correlation between Conscientiousness and the rest of the paranormal belief subscales. The lack of significant relations between Openness and paranormal subscales beyond Spiritualism and Psi were also not predicted, for it was believed that the search for exciting and non conformist ideas, inherent to the Openness factor (McCrae \& Costa, 1997), would leave them more prone to such belief as precognition and extraordinary life forms. Findings regarding Agreeableness also did not support fully our hypothesis since it was significantly related only to Traditional religious belief. Taking this into consideration, we can better understand our three factor model and how it might indicate a novel way of understanding the paranormal belief structure and its relation to personality. The newly formed General paranormal belief (GPB) factor consists of Psi and Spiritualism scales, along with other items from the Witchcraft, Precognition and Extraordinary life forms scales that were not explicitly related to a person (i.e. a witch), a system (i.e. astrology) or to an extent to a creature 
DRUŠ. ISTRAŽ. ZAGREB GOD. 21 (2012),

BR. 1 (115)

STR. 181-201

MIKLOUŠIĆ, I., MLAČIĆ, B., MILAS, G.:

PÁRANORMAL BELIEFS. (i.e. Loch Ness monster). Upon reviewing the included items, it is evident how this factor combines all the non explicit paranormal beliefs that focus on an idea of non physical transcendent energy. Traditional religious belief factor retained the items of Tobacyk's Traditional religious beliefs (TRB) scale, indicating a strong independence of religious beliefs from other paranormal beliefs. Finally, Rituals and practices (RAP) factor contains Superstition subscale along with items explicitly depicting Witchcraft (i.e. Witches do exist), divination systems (e.g. Astrology is a way to accurately predict the future) and a cryptozoological creature (i.e. Loch Ness monster). It is worth noticing how this division separated meaningfully the previously questioned scale of Precognition (Lawrence, 1995a) and also implied a structural issue for the Witchcraft scale. Division of the Extraordinary life forms scale however, was treated as a random fluctuation, rather than a meaningful division due to extremely low support for both cryptozoological claims. Bearing all this in mind, the possible significance of personality in explaining the structure of our three factor model can be seen through comparison of the results reported in Tables 2 and 3. There we can see how all dimensions of paranormal belief that were relevant to a single of the three most important personality factors in this relation (i.e. Neuroticism, Conscientiousness and Openness) went on to constitute a higher order paranormal belief factor. The dimensionality of paranormal beliefs could therefore easily be regarded through its relevance to personality. Starting from Neuroticism, it is presumed that the mediator between the two is the need for a sense of understanding and meaning of the physical and social world (Alcock, 1981). Anxious individuals would therefore have a strong need for control. In an attempt to overcome perceived uncertainty in their surroundings, they would be more susceptible to superstitions since they provide an illusory sense of control over life's unpredictable events (Irwin, 2000). This relation between Neuroticism and superstition has been repeatedly confirmed (Williams et al., 2007; Wiseman \& Watt, 2004), however, due to the traditional division of scales by Tobacyk (1988), the wider picture could have eluded us. For example, since Neuroticism was related to RAP factor $(0.23$, $\mathrm{p} \leq 0.001$ ), we could hypothesize that this factor represents aspects of paranormal beliefs relevant for anxiousness regulation. It included beliefs in witches and astrology which, along with Superstition, imply a possibility of predicting and controlling the outside world and avoiding negative life outcomes (e.g., knocking on wood, asking for a miracle cure or looking for a job only when Jupiter aligns with Mars). Should we accept that interpretation, it becomes clear how there could be a deeper, more salient structure hidden behind those des- 
DRUŠ. ISTRAŽ. ZAGREB GOD. 21 (2012), BR. 1 (115),

STR. 181-201

MIKLOUŠIĆ, I., MLAČIĆ, B., MILAS, G.:

PARANORMAL BELIEFS. criptive paranormal dimensions, and it might very well be related to personality. In regard to Conscientiousness, we have confirmed our hypothesis of positive relation to Traditional religious belief $(0.17, \mathrm{p} \leq 0.001)$. This presumably stems from the characteristics of conscientious people; mainly orderliness, self-discipline, self-control, impulse control, desirability, conformity, restraint (Costa \& McCrae, 1992) and even orthodoxy (Saroglou, 2002). Also, since the church explicitly judges all other forms of spiritualism and alternate religiousness, negative relationships of Conscientiousness with General paranormal belief $(-0.13, p \leq 0.005)$ were rightfully expected. Here again we might see how, by using the three factors, no valuable information in regard to personality was lost as Tobacyk's (1988) original subscale related with Conscientiousness remained intact. Finally, in accordance with our hypothesis, Openness was related to Psi $(0.16, \mathrm{p} \leq 0.001)$ and Spiritualism $(0.35, \mathrm{p} \leq 0.001)$, while being negatively related to Traditional religious beliefs $(-0.26, p \leq 0.001)$, presumably through receptiveness to new ideas, preference for novelty, intellectual curiosity and liberal values (Costa \& McCrae, 1992). This relation was further replicated in the three-factor paranormal structure without loss of meaningful information, as both Psi and Spiritualism formed a unitary factor of General paranormal belief and the Traditional religious beliefs factor remained the same as in the seven factor solution. Although we presumed that Openness would to some extent be related to all paranormal beliefs, it was related only to the subscales later included in the General paranormal belief factor, implying a meaningful, possibly personality driven latent structure that goes beyond simple descriptive categories.

Finally, we propose how an evolutionary viewpoint might prove useful in enlightening this division and its reflection $\mathrm{u}-$ pon personality dimensions. More specifically, we will attempt to view the three factors of paranormal belief and their relation to personality through three currently proposed interpretations of the evolution of paranormal ideation that can roughly be labeled as - byproduct, exaptation and adaptation. It is our belief that only with adopting findings from evolutionary religious studies can we hope to offer a meaningful hierarchical and integrative model of paranormal beliefs, and its relation to personality dimensions. First, we will view it through the research implying the innateness of paranormal beliefs (e.g. Boyer, 1994, 2003; Barrett, 2000). Founded on well defined, cognitive determinants instead of hypothetical ontological domains, this approach utilizes knowledge from developmental, evolutionary and cognitive psychology. Within it, all paranormal, superstitious and magical beliefs are interpreted as a by-product of cognitive processes and as ontolo- 
DRUŠ. ISTRAŽ. ZAGREB GOD. 21 (2012),

BR. 1 (115),

STR. 181-201

MIKLOUŠIĆ, I., MLAČIĆ, B., MILAS, G.:

PARANORMAL BELIEFS gical confusions of our core knowledge about the world; mainly, our intuitive physics, intuitive biology and intuitive psychology (Lindeman \& Aarnio, 2007), implying how they will in some form be present without any social influence or interpersonal need. This concept of ontological confusions, however, precisely sums up the wide variety of paranormal beliefs that are represented in the newly formed General paranormal beliefs dimension. It is interesting to note how certain personality dimensions, mainly Openness, are attracted to this sort of imagination, and still very little is known on the interaction between the personality and our supernaturalizing propensity. On the second level of this evolutionary analysis, we focus on the active role paranormal ideas and beliefs have taken in order to secure meaning to individuals able to perceive them. Norenzayan and Hansen (2006) offer a good example with an evolutionary adoption of the terror management theory (Greenberg et al., 1997), implying how, after evolving to self-consciousness, humans faced paralyzing consequences of fear of death. It is proposed that the most "fit" individuals adapted by using our pre-existing propensity toward supernatural and creating non-realistic but comforting beliefs that allow them to survive or find comfort. Again, a parallel could be drawn to our third factor, Rituals and practices, which seemingly describes precisely that aspect of paranormal beliefs. Its relevance to anxiety control is shown by significant correlation with Neuroticism. Finally, the third level is our capacity for supernatural ideation and its relation to organized religion. This evolutionary view promotes the idea how our ability to perceive a divine force, which prescribed and controlled a set of strict rules, could have been a necessary prerequisite for cooperation and prevention of cheating behavior in large social groups. Thus, our supernaturalizing propensity is viewed as a possible source of fitness in a competitive social and cultural scene (e.g. Alcorta \& Sosis, 2005; Bering et al., 2005; Norenzayan \& Shariff, 2008; Wilson, 2002). We can see how this aspect of paranormal ideation has also emerged as a distinct factor in our structure (Traditional religious belief), again relating to one specific personality trait; i.e. Conscientiousness. Since the role of, not only paranormal beliefs, but also personality dimensions is already recognized through an evolutionary perspective (Buss, 1991, 2009), this relation might prove relevant and it is our suggestion for it to be further explored in the future. If a division of paranormal beliefs, according to the above stated evolutionary perspectives, is to be confirmed, we might finally approach a broad and meaningful theory of paranormal beliefs, as well as shed more light on evolutionary origins of personality structure. This integration could also once more enable us to conclude 
DRUŠ. ISTRAŽ. ZAGREB GOD. 21 (2012),

BR. 1 (115),

STR. 181-201

MIKLOUŠIĆ, I., MLAČIĆ, B., MILAS, G.:

PARANORMAL BELIEFS... how, as Dobzhansky (1973) once stated for biology - nothing in psychology makes sense except in the light of evolution.

There are however some limitations to our study. First and foremost, we point to the limitations of our sample, all being drawn from a rather young and educated population, who for various educational and intellectual reasons might approach the subject of paranormal beliefs in a specific manner. Furthermore, our conclusions were both determined and limited by the measures used. Although the RPBS captures a wide sample of paranormal beliefs, there is a good reason to believe that many of those beliefs are left out, as for example alternative medicine beliefs, various omens of luck, vital energy beliefs and even food related paranormal beliefs (Lindeman \& Aarnio, 2006; Lindeman et al., 2000). Further studies should work towards implementation of both global and culture specific items in order to provide more validity to these conclusions. As for personality, a facet level approach might prove useful in plotting specific mechanisms within a trait, responsible for paranormal belief acquisition. Also, we must note how the relations between the two domains were modest; making the exploration on a wider sample and the use of more specific, facet level measures even more necessary. Finally, since our theoretical venture in this paper to an extent surpasses the implications of our data, it is evident that a more intensive work on this aspect of paranormal belief is needed, and the integration of the two strongly emerging fields of cognitive and evolutionary psychology with the psychology of individual differences seems to be a promising path. Apart from personality measures, future researchers into this evolutionary-individualist paradigm would do well to include other already well explored and evolutionary relevant factors (e.g. intelligence, gender, mating value, etc.) Hopefully, it will be able to bring us closer to understanding this complex and intriguing human characteristic and help us finally enlighten what Sagan (1995) prosaically depicted as the "demon haunted world".

Alcock, J. E. (1981), Parapsychology: Science or Magic? A Psychological Perspective, Elmsford, Pergamon Press.

Alcock, J. E. and Otis, L. P. (1980), Critical Thinking and Belief in the Paranormal. Psychological Reports, 46: 479-482. doi:10.2466/pr0.1980. 46.2.479

Alcorta, C. S. and Sosis, R. (2005), Ritual, Emotion, and Sacred Symbols: The Evolution of Religion as an Adaptive Complex. Human Nature, 16 (4): 323-359. doi:10.1007/s12110-005-1014-3

Barrett, J. L. (2000), Exploring the Natural Foundations of Religion. Trends in Cognitive Science, 4 (1): 29-34. doi:10.1016/S1364-6613(99) 01419-9 
DRUŠ. ISTRAŽ. ZAGREB GOD. 21 (2012), BR. 1 (115)

STR. 181-201

MIKLOUŠIĆ, I., MLAČIĆ, B., MILAS, G.:

PARANORMAL BELIEFS.
Bering, J. M., McLeod, K. A. and Shackelford, T. K. (2005), Reasoning about Dead Agents Reveals Possible Adaptive Trends. Human Nature, 16 (4): 360-381. doi:10.1007/s12110-005-1015-2

Boyer, P. (1994), The Naturalness of Religious Ideas. A Cognitive Theory of Religion, Berkeley-Los Angeles, University of California Press.

Boyer, P. (2003), Religious Thought and Behaviour as By-Products of Brain Function. Trends in Cognitive Sciences, 7 (3): 119-124. doi:10. 1016/S1364-6613(03)00031-7

Buss, D. M. (1991), Evolutionary Personality Psychology. Annual Review of Psychology, 42: 459-491. doi:10.1146/annurev.ps.42.020191.002331

Buss, D. M. (2009), How Can Evolutionary Psychology Successfully Explain Personality and Individual Differences? Perspectives on Psychological Science, 4 (4): 359-366. doi:10.1111/j.1745-6924.2009.01138.x

Cattell, R. B. (1966), The Scree Test for the Number of Factors. Multivariate Behaviour Research, 1 (2): 245-276. doi:10.1207/s15327906mbr $0102 \_10$

Coon, D. J. (1992), Testing the Limits of Sense and Science: American Experimental Psychologists Combat Spiritualism, 1880-1920. American Psychologist, 47 (2): 143-151. doi:10.1037//0003-066X.47.2.143

Costa, P. T. and McCrae, R. R. (1992), Revised NEO Personality Inventory (NEO-PI-R) and the NEO Five Factor Inventory (NEO-FFI) Professional Manual. Odessa, FL, Psychological Assessment Resources.

Díaz-Vilela, L. Y. and Álvarez-González, C. J. (2004), Differences in Paranormal Beliefs across Fields of Study from a Spanish Adaptation of Tobacyk's RPBS. Journal of Parapsychology, 68 (2): 405-421.

Dobzhansky, T. (1973), Nothing in Biology Makes Sense Except in the Light of Evolution. The American Biology Teacher, 35: 125-129.

Egan, V., Auty, J., Miller, R., Ahmadi, S., Richardson, C. and Gargan, I. (1999), Sensational Interests and General Personality Traits. The Journal of Forensic Psychiatry, 10 (3): 567-582. doi:10.1080/09585189908402160

Eysenck, H. J. (1991), Dimensions of Personality: 16, 5, or 3? - Criteria for a Taxonomic Paradigm. Personality and Individual Differences, 12 (8): 773-790. doi:10.1016/0191-8869(91)90144-Z

Fichten, C. S. and Sunerton, B. (1983), Popular Horoscopes and the "Barnum Effect." Journal of Psychology, 114 (1): 123-134. doi:10.1080/ 00223980.1983.9915405

Gallagher, C., Kumar, V. K. and Pekala, R. J. (1994), The Anomalous Experiences Inventory: Reliability and Validity. Journal of Parapsycho$\log y, 58:$ 402-428.

Goldberg, L. R., Johnson, J. A., Eber, H. W., Hogan, R., Ashton, M. C., Cloninger, C. R. and Gough, H. G. (2006), The International Personality Item Pool and the Future of Public-Domain Personality Measures. Journal of Research in Personality, 40 (1): 84-96. doi:10.1016/j.jrp. 2005.08.007

Goulding, A. (2005), Healthy Schizotypy in a Population of Paranormal Believers and Experients. Personality and Individual Differences, 38 (5): 1069-1083. doi:10.1016/j.paid.2004.07.006 
DRUŠ. ISTRAŽ. ZAGREB GOD. 21 (2012),

BR. 1 (115),

STR. 181-201

MIKLOUŠIĆ, I., MLAČIĆ, B., MILAS, G.:

PARANORMAL BELIEFS...
Gračanin, A., Kardum, I. and Krapić, N. (2004), Odnos pridjevske i upitničke mjere dimenzija petofaktorskog modela ličnosti [The Relation between Adjective and Questionnaire Measures of the Five Factor Model of Personality Dimensions]. Psihologijske teme, 13 (1): 33-46.

Greenberg, J., Solomon, S. and Pyszczynski, T. (1997), Terror Management Theory of Self-Esteem and Cultural Worldviews: Empirical Assessments and Conceptual Refinements. Advances in Experimental Social Psychology, 29: 61-139. doi:10.1016/S0065-2601(08)60016-7

Hartman, S. E. (1999), Another View of the Paranormal Belief Scale. The Journal of Parapsychology, 63 (2): 131-141.

Horn, J. L. (1965), A Rationale and Test for the Number of Factors in Factor Analysis. Psychometrika, 30 (2): 179-185. doi:10.1007/BF02289447

International Personality Item Pool. A Scientific Collaboratory for the Development of Advanced Measures of Personality Traits and Other Individual Differences. http://ipip.ori.org/ (19. 2. 2010)

Irwin, H. J. (1993), Belief in the Paranormal: A Review of the Empirical Literature. Journal of the American Society for Psychical Research, 87 (1): 1-39.

Irwin, H. J. (2000), Belief in the Paranormal and a Sense of Control over Life. European Journal of Parapsychology, 15: 68-78.

Irwin, H. J. (2009), The Psychology of Paranormal Belief: A Researcher's Handbook, Hertfordshire, University of Hertfordshire Press.

Lange, R., Irwin, H. J. and Houran, J. (2000), Top-Down Purification of Tobacyk's Revised Paranormal Belief Scale. Personality and Individual Differences, 29 (1): 131-156. doi:10.1016/S0191-8869(99)00183-X

Lawrence, T. R. (1995a), How Many Factors of Paranormal Belief are There?: A Critique of the PBS. Journal of Parapsychology, 58: 3-25.

Lawrence, T. R. (1995b), Moving on from the Paranormal Belief Scale: A Final Reply to Tobacyk. Journal of Parapsychology, 59: 131-140.

Lawrence, T. R. and De Cicco, P. (1997), The Factor Structure of the Paranormal Belief Scale: More Evidence in Support of the Oblique Five. Journal of Parapsychology, 61 (3): 243-251.

Lawrence, T. R., Roe, C. A. and Williams, C. (1997), Confirming the Factor Structure of the Paranormal Beliefs Scale: Big Orthogonal Seven or Oblique Five? The Journal of Parapsychology, 61 (1): 13-31.

Lindeman, M. and Aarnio, K. (2006), Paranormal Beliefs: Their Dimensionality and Correlates. European Journal of Personality, 20 (7): 585-602. doi:10.1002/per.608

Lindeman, M. and Aarnio, K. (2007), Superstitious, Magical, and Paranormal Beliefs: An Integrative Model. Journal of Research in Personality, 41 (4): 731-744. doi:10.1016/j.jrp.2006.06.009

Lindeman, M., Keskivaara, P. and Roschier, M. (2000), Assessment of Magical Beliefs about Food and Health. Journal of Health Psychology, 5 (2): 195-209. doi:10.1177/135910530000500210

MacDonald, D. A. (2000), Spirituality: Description, Measurement, and Relation to the Five Factor Model of Personality. Journal of Personality, 68 (1): 153-197. doi:10.1111/1467-6494.t01-1-00094 
DRUŠ. ISTRAŽ. ZAGREB GOD. 21 (2012), BR. 1 (115)

STR. 181-201

MIKLOUŠIĆ, I., MLAČIĆ, B., MILAS, G.: PARANORMAL BELIEFS
Marinović Jerolimov, D. (2005), Tradicionalna religioznost u Hrvatskoj 2004.: između kolektivnoga i individualnoga [Traditional Religiosity in Croatia in 2004: Between the Collective and Individual. Sociologija sela, 43 (2): 303-338.

McCrae, R. R. and Costa, P. T., Jr. (1997), Conceptions and Correlates of Openness to Experience. In: R. Hogan, J. A. Johnson and S. R. Briggs (Eds.), Handbook of Personality Psychology (pp. 825-847). Orlando, FL: Academic Press. doi:10.1016/B978-012134645-4/50032-9

Mlačić, B. and Goldberg, L. R. (2007), An Analysis of a Cross-Cultural Personality Inventory: The IPIP Big-Five Factor Markers in Croatia. Journal of Personality Assessment, 88 (2): 168-177. doi:10.1080/00223890 701267993

Moore, D. W. (2005.), Three in Four Americans Believe in Paranormal. Gallup Poll, Princeton, NJ: Gallup. http://www.gallup.com/poll/16915/ Three-Four-Americans-Believe-Paranormal.aspx (16. 4. 2010)

Norenzayan, A. and Hansen, I. G. (2006), Belief in Supernatural Agents in the Face of Death. Personality and Social Psychology Bulletin, 32 (2): 174-187. doi:10.1177/0146167205280251

Norenzayan, A. and Shariff, A. F. (2008), The Origin and Evolution of Religious Prosociality. Science, 322 (5898): 58-62. doi:10.1126/science. 1158757

Rattet, S. L. and Bursik, K. (2001), Investigating the Personality Correlates of Paranormal Belief and Precognitive Experience. Personality and Individual Differences, 31 (3): 433-444. doi:10.1016/S01918869(00)00148-3

Sagan, C. (1995), The Demon-Haunted World: Science as a Candle in the Dark, New York, Random House.

Saroglou, V. (2002), Religion and the Five Factors of Personality: A Meta-Analytic Review. Personality and Individual Differences, 32 (1): 15-25. doi:10.1016/S0191-8869(00)00233-6

Saroglou, V. and Jaspard, J.-M. (2000), Personality and Religion: From Eysenck's Taxonomy to the Five-Factor Model. Archive for the Psychology of Religion, 23 (1): 41-70. doi:10.1163/157361200X00050

Saucier, G. (1992), Openness versus Intellect: Much Ado about Nothing? European Journal of Personality, 6 (5): 381-386. doi:10.1002/per .2410060506

Saucier, G. (2000), Isms and the Structure of Social Attitudes. Journal of Personality and Social Psychology, 78 (2): 366-385. doi:10.1037//0022-3514. 78.2.366

Saucier, G. and Skrzypińska, K. (2006), Spiritual But Not Religious? Evidence for Two Independent Dispositions. Journal of Personality, 74 (5): 1257-1292. doi:10.1111/j.1467-6494.2006.00409.x

Smith, C. L., Johnson, J. L. and Hathaway, W. (2009), Personality Contributions to Belief in Paranormal Phenomena. Individual Differences Research, 7: 85-96.

Thalbourne, M. A. (1994), Belief in the Paranormal and Its Relationship to Schizophrenia-Relevant Variables: A Confirmatory Study. British Journal of Clinical Psychology, 33 (1): 78-80. doi:10.1111/j.20448260.1994.tb01097.x 
DRUŠ. ISTRAŽ. ZAGREB GOD. 21 (2012),

BR. 1 (115),

STR. 181-201

MIKLOUŠIĆ, I., MLAČIĆ, B., MILAS, G.:

PARANORMAL BELIEFS...
Thalbourne, M. A. and Delin, P. S. (1993), A New Instrument for Measuring the Sheep-Goat Variable: Its Psychometric Properties and Factor Structure. Journal of the Society for Psychical Research, 59: 172-186. Thalbourne, M. A., Dunbar, K. A. and Delin, P. S. (1995), An Investigation into Correlates of Belief in the Paranormal. Journal of the Society for Physical Research, 89: 215-231.

Thalbourne, M. A. and French, C. C. (1995), Paranormal Belief, Manic-Depressiveness, and Magical Ideation: A Replication. Personality and Individual Differences, 18 (2): 291-292. doi:10.1016/0191-8869 (94)00146-J

Thalbourne, M. A. and Haraldsson, E. (1980), Personality Characteristics of Sheep and Goats. Personality and Individual Differences, 1 (2): 180-185. doi:10.1016/0191-8869(80)90040-9

Tobacyk, J. J. (1982), Paranormal Belief and Trait Anxiety. Psychological Reports, 51: 861-862. doi:10.2466/pr0.1982.51.3.861

Tobacyk, J. J. (1988), A Revised Paranormal Belief Scale, Unpublished manuscript, Louisiana Tech University, Ruston, LA.

Tobacyk, J. J. (1995), Final Thoughts on Issues in the Measurement of Paranormal Beliefs. Journal of Parapsychology, 59: 141-145.

Tobacyk, J. J. and Milford, G. (1983), Belief in Paranormal Phenomena: Assessment Instrument Development and Implications for Personality Functioning. Journal of Personality and Social Psychology, 44 (5): 1029-1037. doi:10.1037//0022-3514.44.5.1029

Tobacyk, J. J. and Mitchell, T. (1987), Out-of-Body Experience Status as a Moderator of Effects of Narcissism on Paranormal Beliefs. Psychological Reports, 60: 440-442. doi:10.2466/pr0.1987.60.2.440

Tobacyk, J. J., Nagot, E. and Mitchell, T. (1989), Prediction of Future Events Scale: Assessment of Beliefs about Predicting the Future. The Journal of Social Psychology, 129 (6): 819-823. doi:10.1080/00224545. 1989.9712090

Tobacyk, J. J. and Thomas, A. (1997), How the Big Orthogonal Seven is Really the Oblique Seven. Journal of Parapsychology, 61: 337-342.

Tobacyk, J. J. and Wilkinson, L. V. (1990), Magical Thinking and Paranormal Beliefs. Journal of Social Behavior and Personality, 5: 255-264.

Williams, E., Francis, L. J. and Robbins, M. (2007), Personality and Paranormal Belief: A Study among Adolescents. Pastoral Psychology, 56 (1): 9-14. doi:10.1007/s11089-007-0094-x

Wilson, D. S. (2002), Darwin's Cathedral: Evolution, Religion, and the Nature of Society, Chicago, IL, University of Chicago Press.

Windholz, G. and Diamant, L. (1974), Some Personality Traits of Believers in Extraordinary Phenomena. Bulletin of the Psychonomic Society, 3: 125-126.

Wiseman, R. and Watt, C. (2004), Measuring Superstitious Belief: Why Lucky Charms Matter. Personality and Individual Differences, 37 (8): 1533-1541. doi:10.1016/j.paid.2004.02.009 
DRUŠ. ISTRAŽ. ZAGREB GOD. 21 (2012),

BR. 1 (115)

STR. 181-201

MIKLOUŠIĆ, I., MLAČIĆ, B., MILAS, G.:

PARANORMAL BELIEFS

\section{Paranormalna vjerovanja i osobine ličnosti u Hrvatskoj}

Igor MIKLOUŠIĆ, Boris MLAČIĆ, Goran MILAS

Institut društvenih znanosti Ivo Pilar, Zagreb

Cilj ove studije bilo je istraživanje povezanosti peterofaktorskoga modela ličnosti i paranormalnih vierovanja. Sudionici istraživanja $(N=307)$ bili su studenti Sveučilišta u Zagrebu (Hrvatska). Od miera je primijenjena IPIP verzija upitnika peterofaktorskoga modela (Goldberg i sur., 2006.) te revidirana skala paranormalnih vjerovanja (Tobacyk, 1988.). Faktorska analiza revidirane skale paranormalnih vjerovanja upozorila je na, do sada nezabilježenu, trofaktorsku strukturu, pri čemu su dobivene dimenzije nazvane: generalna paranormalna vjerovanja, tradicionalna religijska vjerovanja i rituali i prakse. Najznačajnije povezanosti ličnosti s dimenzijama paranormalnih vjerovanja nađene su za faktore otvorenosti, savjesnosti i neuroticizma. Rezultati su djelomično potvrdili prijašnje nalaze, pokazujući sklonost otvorenijih pojedinaca prema generalnim paranormalnim vjerovanjima i odbacivanju tradicionalnih religijskih vjerovanja. Dimenzija savjesnosti pokazala se pozitivno povezana s tradicionalnim religijskim, a negativno s generalnim paranormalnim vjerovanjima. Neuroticizam se pokazao povezan s ritualima i praksama, ti. praznovjerjem, proricanjem i okultnim praksama. Povezanosti su se pokazale umjerenima $(0,11$ $0,25)$, a novootkrivena struktura paranormalnih vjerovanja i njezina povezanost s osobinama ličnosti promatrana je kroz evolucijsku perspektivu. Ograničenja i smjernice za buduće istraživače naznačene su na kraju.

Ključne riječi: paranormalna vjerovanja, osobine ličnosti, Tobacyk, peterofaktorski model, evolucija 